\title{
ANALYSIS OF INTERACTIONS ON NON-PROFIT ORGANIZATION'S SOCIAL MEDIA CHANNEL IN THE CONTEXT OF CRUELTY-FREE ETHICAL CONSUMERISM
}

\author{
Patricia Fux \\ Faculty of Economics,University of Ljubljana, Slovenia \\ patricia.fux@gmail.com \\ Barbara Čater \\ Faculty of Economics,University of Ljubljana, Slovenia \\ barbara.cater@ef.uni-lj.si
}

\begin{abstract}
Social media offer non-profit organizations a new, convenient, cheap, and wide reach medium to spread their messages, increase awareness and connect with supporters. The main objective of this study is to examine interactions on social media to understand how people engage with the content published by non-profit organizations. This study is set in the context of cruelty-free ethical consumerism and data for analysis were collected from the international non-profit organization People for the Ethical Treatment of Animals (PETA) official Facebook page. Study points out that lack of awareness and knowledge is one of the main reasons why people do not behave ethically and therefore do not follow the studied organization's main goal. However, once awareness and information are gained, individual may reach epiphany and willingness to change behaviour. At that point individuals also showed support to organization's main goal. The research shows that content with informational component received the most engagement on average and supporting comments were prevailing. Informational content is perceived as especially valuable when there is a lack of knowledge about the topic and therefore such content is recommended to non-profit organizations to raise awareness, create new and strengthen relationships with existing supporters.
\end{abstract}

Abstract

Keywords: social media; interaction; non-profit organizations; cruelty-free ethical consumerism; netnography

\section{INTRODUCTION}

Non-profit organizations (hereafter NPOs), charities and organizations alike are important to our society since they work on specific social or environmental issues; they advocate, provide information, take action, and contribute to the better society. NPOs are not homogenous; they substantially vary in size, deal with different issues and perform distinct activities with significantly different budgets (UK Parliament, 2017). Nevertheless, all NPOs follow the same goals; they aim to raise awareness about the social cause they advocate, provide information to public, create and maintain relationships with supporters and secure monetary support (Persuad, Madill, \& Rubaj, 2009). However, NPOs face constant funding challenges (Bandyopadhyay \& Dayton, 2013; Persuad et al., 2009), weak engagement and in the past, such organizations faced also significant communication barriers (Bandyopadhyay \& Dayton, 2013), since wide reach traditional communication channels were too expensive for most NPOs (Persuad et al., 2009).

Around year 2004, Web 2.0 introduced social media, interactive websites that encourage user participation (Berthon, Pitt, Plangger \& Shapiro, 2012). The Internet and social media supplement 
Patricia Fux, Barbara Čater: Analysis of Interactions on Non-Profit Organization's Social Media Channel in the Context of Cruelty-Free Ethical Consumerism

traditional communication venues (Kietzmann, Hermkens, McCarthy \& Silvestre, 2011; Mano, 2014) and enable NPOs to reach very specific audiences around the globe (Berthon et al., 2012), quickly disseminate information at minimal cost (Mano, 2014), influence public opinion, cultivate new supporters (Driscoll, 2009; Persuad et al., 2009), create twoway dialogues with their supporters (Kietzmann et al., 2011) and maintain meaningful relationships with stakeholders, which is of crucial importance for NPOs survival (Bandyopadhyay \& Dayton, 2013). Consequently, social media channels were quickly adopted by NPOs, charities and organizations alike (Campbell, Lambright \& Wells, 2014; Goldkind, 2015; Mano 2014; Nah \& Saxton, 2012; Waters \& Feneley, 2013).

Although several researchers studied how NPOs use social media to achieve specific goals such as raising awareness, building organizational identity or engaging with stakeholders (Cho, Schweickart, \& Haase, 2014; Davis, Rountree, \& Davis, 2016; Lovejoy \& Saxton, 2012; Waters, Burnett, Lamm, \& Lucas, 2009; Waters \& Jones, 2011), less is known about the use of social media in the area of ethical consumerism. Ethical consumerism is voicing ethical concerns about products and practices through choosing to purchase only products that meet individual's ethical criteria (Cho \& Krasser, 2011). Ethical consumerism is gaining momentum due to social media, as they are a convenient tool for quick dissemination of information that contributes to higher awareness, exposure of malpractices, exchange of opinions and concerns, and therefore social media also facilitate ethical behaviour offline (Wyrwoll, 2014). Despite the significant increase in popularity of both social media and ethical consumerism, the literature linking the two topics is scarce. Nevertheless, a few parallels can be drawn from studies analysing Fair-trade consumption attitudes, intentions and patterns since crueltyfree and Fair-trade ethical consumption preferences are largely driven by altruistic motives. The need therefore exists to examine relationships between consumers and NPOs in the context of ethical consumerism in social media.

The main objective of this study is to examine interactions on social media to understand how and why people engage with the content published by
NPOs in the context of cruelty-free consumerism. Thereupon, the paper aims to provide insights about what kind of content type and category perform best in terms of engagement in such context and investigate characteristics of user reactions to content in form of comments in order to understand people's motives for engagement with the content. This article addresses two main research questions: (1) which content type and which content category receive the most engagement, in terms of likes, shares and comments; and (2) what kind of reactions, in form of comments, content generates and how these reactions differ across different areas within cruelty-free context?

As a result, the study aims to contribute to academic literature by providing insights into relationship dynamics between NPOs and consumers in the context of ethical consumerism and social media. Despite the qualitative nature of this study, the discussion contributes to a better understanding of behavioural and communication patterns related to ethical discourse, which does not receive much attention in traditional media. Moreover, the findings and implications can be relevant to a wide array of NPOs in order to create meaningful content, which sparks conversation, engagement and contributes to cultivating and maintaining long-term relationships with supporters.

\section{LITERATURE REVIEW}

\subsection{Social media}

Compared to traditional media, social media can reach wider population at lower costs, which contributes to higher awareness and increased exposure of social issues. That is essential for NPOs, which usually operate with small budgets for public relations activities and are therefore oftentimes unable to reach wider population via more expensive traditional media. In contrast to traditional media, social media enable a two-way communication and therefore a conversation with its supporters can be established. Conversation is an important driver for engagement and consequently of vital importance for NPOs; higher engagement increases likelihood of donations or participation in other desired actions (Bandyopadhyay \& Dayton, 2013). 
Social media have become a medium for the fastest dissemination of information, efficient in spreading awareness, creating buzz and building relationships (Phethean Tiropanis \& Harris, 2015). Hence, social networks serve as an informational and entertainment tool in order to maintain relationships, meet like-minded people, obtain useful information and find social support (Huang, 2013). Especially Facebook is perceived as very engaging as it also features groups of people with shared lifestyle or attitudes via which individuals track action, beliefs and interests of the group to which they belong (Joinson, 2008).

Most importantly, social media amplify information flow between supporters and NPOs, which leads to increase in exposure to social issues (Mano, 2014) and therefore social media provide NPOs the muchneeded platform for relationship development and maintenance with its stakeholders. As a result, social media enhance voluntary engagement, increase willingness to support social issues (Molm, 2010; Molm, Collett \& Schaefer, 2007) and proved to be an important channel for NPOs to increase monetary contributions (Mano, 2014), and mobilize public to take action (Lovejoy \& Saxton, 2012). Notably, social networking strengthens loyalty to online communities, which facilitate knowledge transfer (Wyrwoll, 2014) and results in individual's pro-social behaviour online as well as offline (Mano, 2014).

Facebook pages or communities provide relevant informational, social and entertainment content and are perceived as interesting and worth visiting, as they help individuals with better purchase or other decisions (Lin \& Lu, 2011). Such pages also encourage customer-to-customer interactions (Ruiz-Mafe, Martí-Parreño \& Sanz-Blas, 2014). The most common factors for participation derive from need for information and can be specified as: venting negative feelings, showing concern for others by expressing opinion, seeking advice, helping the organization, obtaining social benefits or embracing self-enhancement (Brodie et al., 2013). Consequently, it can be argued that such pages are used for sharing, learning, socializing, advocating and co-developing where in turn participants gain personal satisfaction, empowerment, and connection to the community and strengthen commitment.
Many researchers have analyzed content type on Facebook pages of many different companies, including Fortune 500 companies and top global brands. All reviewed studies employed quantitative analyses and measured engagement with Like, Comment and Share. Majority of the reviewed literature came to conclusion that photo or video generated more likes than other types of content, such as links and text-only. Several researchers (Cvijikj \& Michahelles, 2011, 2013; Kim, Spiller, \& Hettche, 2015; Luarn, Lin, \& Chiu, 2015; Sabate, Berbegal-Mirabent, Cañabate, \& Lebherz, 2014; Valerio, Herrera-Murillo, Villanueva-Puente, Herrera-Murilloand, \& Rodríguez, 2015) found that photos are the best performers in generating likes. It is suggested that followers opt not to watch videos since it takes too much time whereas images are easier to digest (Sabate et al., 2014; Kim et al., 2015), which directly relates to theory of vividness and interactivity of content used on Facebook.

Comment function is more time consuming than Like and Share, as it invites individuals to showcase their own opinion and is therefore also more engaging since it stimulates creation of conversations and debates. In previous research photos were found to generate the most comments (Sabate et al., 2014; Phethean, Tiropanis, \& Harris, 2015) and links were found to generate the least comments as the content consumer is redirected to an external webpage and therefore lowering the probability that the viewer will return and comment (de Vries, Gensler \& Leeflang, 2012; Sabate et al., 2014). Moreover, followers tend to generate comments when content is perceived as very meaningful as it stimulates them to publicly express their feelings and opinions (de Vries et al., 2012; Sabate et al., 2014). The studies on shareability of the content show that videos and pictures are more sharable than other content types although, the decision to share is more dependent on content category, rather than on post type (Cvijikj \& Michahelles, 2013).

Studies analysing social media divided the content in different categories, depending on the organization or group of organizations that were subject of the analysis. However, majority of different classifications found in literature can be well summarised with Information-Community-Action 
Patricia Fux, Barbara Čater: Analysis of Interactions on Non-Profit Organization's Social Media Channel in the Context of Cruelty-Free Ethical Consumerism

classification scheme developed by Lovejoy and Saxton (2012) especially for studying organizations' main purposes for the use of social media. Content with Information function is a traditional one-way message and its purpose is only to pass on information to receiver. Community-building function is used to send out messages to the public to encourage dialogue and interaction, with the purpose to create an online community of supporters (Lovejoy \& Saxton, 2012). Lastly, Action is the most demanding (Auger, 2013); messages in this category demand action such as participation, donation, attendance etc. from the follower. It is also recognized as the most tangible since it presents the outcome, the organization's goal (Lovejoy \& Saxton, 2012). Consequently, the Information-CommunityAction categories can be recognized to be in hierarchical order where Information represents a vital activity to raise awareness and allure followers, Community-building serves as a binding agent to retain and engage the followers into meaningful conversations, and at the top of the hierarchy sits Action, with the motive to convince the community to mobilize and perform the organization's main goal (Lovejoy \& Saxton, 2012).

\subsection{Online ethical communities}

Online public group discussions are especially relevant when topic does not receive much attention in other media types and therefore users use such groups to gain more information. Ethical consumerism and ethical issues can be recognized as one of such topics, since online ethical communities are perceived as a valuable source of information (Gummerus, Liljander, \& Sihlman, 2017). Consequently, social media present a valuable source of information that helps consumers to adapt their behavior in accordance with their ethical beliefs (Wyrwoll, 2014). Moreover, particularly Facebook has been found to increase possibilities to communicate and engage with different social causes (Mano, 2014).

Facebook communities serve as a tool to socialize, expand individual's social network, meet like-minded people, find companionship, and social support (Huang, 2013; Joinson, 2008). Hence, Online Ethical Communities (hereafter OEC) serve as a support to like-minded people where they can express their consumption choices, concerns, search for advices and exchange opinions. Such interactions among participants foster knowledge and are perceived as trustworthy and educational source of information, thus helping consumers to cope with cognitive dissonance (Gummerus et al., 2017). Although, those who experience guilt and anxiety may not enjoy in participation yet, they use OEC to reduce negative feelings and find reassurance (Gummerus et al., 2017). Primary benefit for participants is obtaining informational benefits, as ethical communities are cognition driven and therefore provided information is bound to be beneficial (Dholakia, Blazevic, Wiertz \& Algesheimer, 2009; Gummerus et al., 2017). Participants also gain social benefits as they share concern, look for social support and fulfill the need for communication and recognition. Interestingly, it has been discovered that informational benefits reinforce ethical behavior and social benefits increase loyalty and commitment to the community (Gummerus et al., 2017).

In terms of content, OEC provide primarily informational content, as lack of information is reported to be the main issue preventing consumers to behave ethically. Accordingly, OEC provide up-todate information and timely answers, as their main goal is to increase awareness (Uusitalo \& Oksanen, 2004). However, such content is predominantly oneway communication and therefore neither contributes to community-building, which is according to Lovejoy and Saxton (2012) necessary to strengthen loyalty, nor does it contribute to persuading followers to take action. Nevertheless, according to Rodan and Mummery (2016) the primary goal of OEC is to increase awareness on ethical issues and therefore the prevalence of informational content type may be justified.

\subsection{Animal ethics - views on use of animals}

The three main ethical concerns are the environment, human rights and working conditions, and animal welfare (Tallontire, Rentsendorj \& Blowfield, 2001). Animal welfare and animal rights are advocating the wellbeing of the animals yet, animal rights is more progressive than animal welfare. The 
lifestyle that is advocated by animal rights movement is often defined as veganism, yet people frequently associate veganism only with food consumption habits and not with a broader lifestyle. Such lifestyle is defined also as cruelty-free or compassionate lifestyle (Herzog, 1993).

This study is set in the context of cruelty-free ethical consumerism, where people's views on use of animals and similar topics are predicted to be the center of discussion in online ethical communities focusing on cruelty-free consumerism. To illustrate, international NPOs advocating animal rights People for Ethical Treatment of Animals or shortly PETA, advocates that "Animals are not ours to eat, wear, experiment on, use for entertainment or abuse in any other way" (PETA, 2016). Therefore food, clothing, testing and entertainment are defined as the four main areas of cruelty-free aspect of ethical consumerism, since they are also considered to be the industries where the highest number of animals suffers for lengthy periods (Bowmar \& Gow, 2009).

Animal rights movement, which advocates cruelty-free lifestyle, encourages critical thinking about how animals are used in modern society and it has been discovered that people hold different views towards different uses of animals. People may show more favorable views towards using animals for food, which is perceived as a necessity, and simultaneously hold rather negative attitudes toward using animals for entertainment purposes (Knight \& Barnett, 2008). Furthermore, people tend to hold less positive attitudes toward practices, which are lethal for the animals or where animals live in confinement in contrast to non-lethal, observational practices such as zoos and circuses (Furnham, McManus \& Scott, 2003; Knight, Vrij, Cherryman \& Nunkoosing, 2004). Conversely, Atkins-Sayre (2010) identified that practices, such as big game hunt or cockfighting, which do not serve a higher social purpose, are less desirable than animal testing in the name of science. Such findings are in line with Knight and Barnett (2008) who argued that attitudes towards animal use are not uni-dimensional; use of animals for food and medical research, which is perceived as beneficial or necessary, received more support than practices that use animals for fashion and entertainment.
Attitudes towards the use of animals do not vary only among different, above-mentioned areas but also within them. Entertainment was identified as one of the areas that received fairly negative attitudes; especially circuses, rodeos, animal racing and bullfighting are perceived as morally unacceptable (Furnham et al., 2003; Knight \& Barnett, 2008; Knight et al., 2004). Nevertheless, safaris, aquariums and zoos are perceived as acceptable by majority of the population, since they have an educational and conservational component and do not include activities potentially killing or injuring the animals (Shani, 2012).

Different attitudes within the same area were also reported in animal testing and animals used for fashion (Shani, 2012). For instance, people are inclined to support animal use for medical research regardless if the result has a lethal effect on the animal, yet are opposed to animal use for cosmetic testing purposes (Balls, 1992; Knight \& Barnett, 2008; Shani, 2012). It can be argued that people hold stronger negative views towards the use of animals for decoration purposes such as cosmetics and wearing fur, than towards using animals in the name of scientific research (Knight \& Barnett, 2008). However, animals have been used for clothing purposes, in the form of leather, wool and fur, since prehistoric times and have always been highly appreciated for functional and aesthetic purposes (Stone, 2008).

Although, the attitudes are somehow changing in last decades, especially regarding fur products, since people hold strong negative attitudes towards fur, as its purchase is perceived as bad, immoral, foolish and disappointing. Albeit, people still hold somehow neutral attitudes towards leather that is a byproduct of the meat industry and predominantly positive attitudes towards wool (Lundblad \& Davies, 2015: Olson \& Goodnight, 1994). The findings are also to a certain extent consistent with Johnson (1990) who argued that animal use for food or clothing is somehow moral, but strongly opposed to the use of animals for luxury needs, such as fur. Contrarily, Rodan and Mummery (2016) stated that meat industry is one of the major sources of animal cruelty. 
Patricia Fux, Barbara Čater: Analysis of Interactions on Non-Profit Organization's Social Media Channel in the Context of Cruelty-Free Ethical Consumerism

The prime issue animal rights advocates face in relationship to animal consumption is that people are not familiar with meat production process, since the products in grocery stores hardly resemble actual animal flesh and are well-presented in attractive packaging. The reason for such presentation is that people find it unpleasing to eat meat, which closely resembles a living being (Hamilton, 2006; Plous, 1993). The main cause for lack of awareness in the production chain is remoteness; slaughterhouses, meat-packaging plants and farming houses are hidden away from the public eye (Singer, 2006). To illustrate, Plous (1993) reports that only $54 \%$ of participants in a survey, which was made on a representative sample, were able to make a connection between calf and veal, the flesh of 6-7 months old calf. Such dislocation from the process, as consumption practices are not associated with cruelty, often results in shock and cognitive dissonance when a consumer is presented with information and their awareness about the production increases (Plous, 1993).

Knight and Barnett (2008), Lundblad and Davies (2015), Rodan and Mummery (2016) and many others report that lack of awareness and knowledge is one of the main factors influencing why people do not behave ethically. Moreover, if consumers obtain more information and therefore increase awareness, their attitudes are likely to change (Knight \& Barnett, 2008). When a consumer is presented with information and their knowledge and awareness increase, the consumer dilemma or cognitive dissonance is likely to arise, stemming from the realization that individuals' practices have dreadful consequences for the animal (Knight \& Barnett, 2008). People are motivated to restore balance and to decrease dissonance; individuals employ coping mechanisms such as rejection, objectification or searching only for benefits to rationalize unethical behavior. Besides, consumers might even avoid information that causes distress, as they are aware that it will inevitably decrease or eliminate their enjoyment in unethical consumption (Knight \& Barnett, 2008; Rodan \& Mummery, 2016).

In order to increase awareness, stress the importance of ethical issues, organizations often use shocking component in their communications, showcasing terror and horror of production in meat or fur industry (Auger, 2013). Such content tries to minimize the effect of remoteness as the content links together human pleasure in enjoying the product and animal suffering (Atkins-Sayre, 2010). One could argue that such communications try to invert associations from luxury, ordinary, and natural to vulgar, tasteless, savage, and uneducated (Olson \& Goodnight, 1994). Shocking and controversial content may be seen as risky and provocative yet, it stimulates debate. Such content is found to be rather effective as it is reported to lead to epiphany, and thus to conversion from meat consumer to vegetarian or vegan (Rodan \& Mummery, 2016).

\section{METHODOLOGY}

Due to the novelty of the topic and exploratory orientation of this study the authors decided to use qualitative methodology, more specifically netnography. Netnography is a technique developed for studying human interactions online (Kozinets, 2002) and is often used to analyse interactions on social media in form of text, photo, audio, video etc. (Kozinets, 2015). Hence, the method uses information from public forums and alike "to identify and understand the needs and decision influences of relevant online consumer groups" (Kozinets, 2002: 3). "Netnography is a technique of small data search and analysis" (Kozinets, 2015: 175). Thus, this allows the researcher to analyse data in detail and provide meaningful insights (Kozinets, 2015), which may be useful to the broader industry (Kozinets, 2002).

Of social media sites Facebook was selected due to its community size and growth; the number of Facebook users increased from 100 million to 2,129 million between 2008 and the end of 2017 (Facebook users worldwide, 2017). The literature indicated that PETA is a renowned and the largest NPO advocating cruelty-free lifestyle, so PETA's official Facebook page, named PETA - People for the Ethical Treatment of Animals (Facebook.com, 2016b) (hereafter PETA's Facebook) was chosen for data collection for this study. 
The page has content updated several times per day and over four million followers. Consequently, it was expected to yield large amount of interactions and rich insights and therefore a sufficient amount of data. Also, the requirement that interactions must be relevant is fulfilled, since the content relates to all four main uses of animals.

For this research only content published between 15/04/2016 and 15/05/2016 was selected and collected, which includes 110 posts. Table 1 presents the Coding manual 1 , which shows how posts were coded by content category, area and which engagement numbers were collected. During data sample inspection, it was noted that if the cursor is positioned on Like without clicking it, Facebook displays additional new forms of oneclick engagement namely, Love, Haha, Wow, Sad, Angry. At the time of data collection it was decided not to include details of such different one-click interactions in order to make findings more comparable to existing literature. All one-click interactions were collected as a sum and presented as one-click interaction (hereafter OCI). Furthermore, it was discovered that some content possesses Information and Action category characteristics simultaneously, which contradicts Lovejoy and Saxton (2012). Consequently, a classification "Information + Action" was included in Category section of Coding manual 1.

Table 1: Coding manual 1 - Coding posts

\begin{tabular}{|l|l|}
\hline \multirow{4}{*}{ CATEGORY } & Information \\
\cline { 2 - 2 } & Community-building \\
\cline { 2 - 2 } & Action \\
\cline { 2 - 2 } AREA & Information + Action \\
\hline & Entertainment \\
\cline { 2 - 2 } & Food \\
\cline { 2 - 2 } & Fashion \\
\hline \multirow{4}{*}{ ENGAGEMENT } & Testing \\
\hline & Other \\
\hline & Number of OCl \\
\cline { 2 - 2 } & Number of Shares \\
\cline { 2 - 2 } & Number of Comments \\
\hline
\end{tabular}

Since the main objective of this research is to examine the interactions in order to understand how and why people engage with the content, comments were analysed. Following Kozinets (2015) guidelines to analyse small portion of highquality data, only first top 40 comments from the top two posts in number of comments from each specific area in chosen period were collected. Therefore, 320 comments, 80 from each area, were collected, examined and coded. Importantly, top comments are the most relevant comments, automatically defined by Facebook algorithm (Facebook.com, 2016a).

Throughout the analysis Braunsberger and Buckler (2011) approach was adopted, grouping comments into categories based on repeating topics and issues in order to deliver organized and useful findings. Attention was paid to repeating issues, words, meanings, etc. to develop coding categories for grouping comments and deliver structured and synthesized findings. Table 2 presents the Coding manual for coding comments.

\section{RESULTS}

In terms of content category, Figure 1 illustrates that Information+Action generated the most engagement on average in terms of $\mathrm{OCl}$, Comment and Share followed by Information, Communitybuilding and Action category. Information+Action category was far superior compared to others as it generated more engagement than Communitybuilding and Action category combined. Interestingly, Information+Action also generated more than twice as many Shares and Comments on average than Information category. The reason for such result lays in the fact that majority of all Information+Action contnet was video type (Figure 2), which proved to outperform other types in generating Comments and Shares (Figure 1). Moreover, one could suggest that viewers might be more stimulated to engage and take action immediately after they are educated and informed about a certain ethical issue.

It can be concluded that Information+Action outperforms other categories since OEC are primarily utilized for search for information and therefore, 
Patricia Fux, Barbara Čater: Analysis of Interactions on Non-Profit Organization's Social Media Channel in the Context of Cruelty-Free Ethical Consumerism

Table 2: Coding manual 2 - Coding Comments

\begin{tabular}{|c|c|c|c|}
\hline & Coding Category & Explanation & Example \\
\hline \multirow[t]{2}{*}{1} & \multirow[t]{2}{*}{ Supporting the content } & $\begin{array}{l}\text { Venting negative feelings - Content often } \\
\text { showcases mistreatment of animals, passionate } \\
\text { statements, using exclamation marks and } \\
\text { showcasing strong negative emotions such as } \\
\text { anger, sadness, disgust, disappointment in } \\
\text { human race etc. are classified as supportive. }\end{array}$ & $\begin{array}{l}\text { This is so inhumane and wrong!! No living } \\
\text { being deserves to be treated like that!! }\end{array}$ \\
\hline & & $\begin{array}{l}\text { Other - Comments expressing opinions / } \\
\text { concerns / examples supporting the content. }\end{array}$ & $\begin{array}{l}\text { I'm vegan since 2010. Thanks PETA for sharing } \\
\text { such content and raising awareness. Maybe } \\
\text { one day people will understand. }\end{array}$ \\
\hline 2 & Contradicting the content & $\begin{array}{l}\text { Contributor does not agree with the content } \\
\text { and may not be fully aware of the production } \\
\text { process and therefore rejects, objectifies or } \\
\text { searches for benefits to rationalize unethical } \\
\text { behaviour. }\end{array}$ & $\begin{array}{l}\text { Animals are here for us to use. I will continue } \\
\text { eating chicken for dinner and buying quality } \\
\text { leather goods. }\end{array}$ \\
\hline 3 & Seeking advice, asking questions & $\begin{array}{l}\text { Contributor is gaining awareness and } \\
\text { collecting information. }\end{array}$ & Are L'Oreal cosmetics tested on animals? \\
\hline 4 & Epiphany & $\begin{array}{l}\text { Comments showing that the contributor was } \\
\text { unfamiliar with cruelty practices. Contributor } \\
\text { reports feelings of guilt and wishes to make a } \\
\text { change in behaviour. }\end{array}$ & $\begin{array}{l}\text { Oh my god this is so sick!! I will never eat pork } \\
\text { again and I wish I never had!!! }\end{array}$ \\
\hline 5 & Demanding a change & $\begin{array}{l}\text { The contributor showcases strong negative } \\
\text { attitudes towards animal cruelty and } \\
\text { demands a change and/or wishes to take } \\
\text { action personally (signing petitions, asking } \\
\text { government to take action...) }\end{array}$ & $\begin{array}{l}\text { This must stop!! Government should ban } \\
\text { circuses! }\end{array}$ \\
\hline 6 & Showcasing alternatives & $\begin{array}{l}\text { Comments including various cruelty-free } \\
\text { alternatives suggestion. }\end{array}$ & $\begin{array}{l}\text { Cirque du Soleil is a great alternative to } \\
\text { circuses and alike. High quality shows with } \\
\text { only human acrobats! }\end{array}$ \\
\hline
\end{tabular}

Note: All exemplary comments are fictional, constructed based on the analysed comments and therefore not quoted. Data were collected from publicly available website however, the real comments are not disclosed in order to preserve complete contributor's anonymity, which is in line with Kozinets (2015) guidelines.

content with informational component is bound to be interesting and worth engaging with. Moreover, such content seems to generate especially high amount of engagement if presented in video type, since video performed well in generating $\mathrm{OCl}$, Comments and Shares.

Figure 1 depicts that $\mathrm{OCl}$ is dominating across all types, since this is the simplest type of engagement (Jayasingh \& Venkatesh, 2015). On average, Photo received slightly higher $\mathrm{OCl}$ than Video; that is consistent with Sabate et al. (2014) who posited that videos are more time consuming and images are easier to digest. Interestingly, despite the significantly lower performance in $\mathrm{OCl}$, links occupy almost $40 \%$ of the examined content. The rationale may be in fact that majority of links lead to PETA's official webpage to access more in-depth information, since $80.5 \%$ of all links fall into categories with informational component (Figure 2).

Moreover, Figure 1 illustrates that on average, all content types received significantly fewer comments than other types of engagement, since Comment is the most time-consuming (Sabate et al., 2014). However, Video outperformed other content 
types in generating Comments and Shares. Such finding is to a certain extent consistent with Cvijikj \& Michahelles (2013) and Laurn et al. (2015) where Video and Link are defined as interactive and discovered to receive more engagement. Figure 2 depicts a high percentage of content with informational component in form of links and Figure 1 shows that such content performs very well in generating comments. Additionally, people utilize OEC to search for information, so it can be assumed that they are more willing to engage in discussions (Gummerus et al., 2017).

Figure 1: Average numbers of engagement per content category and type

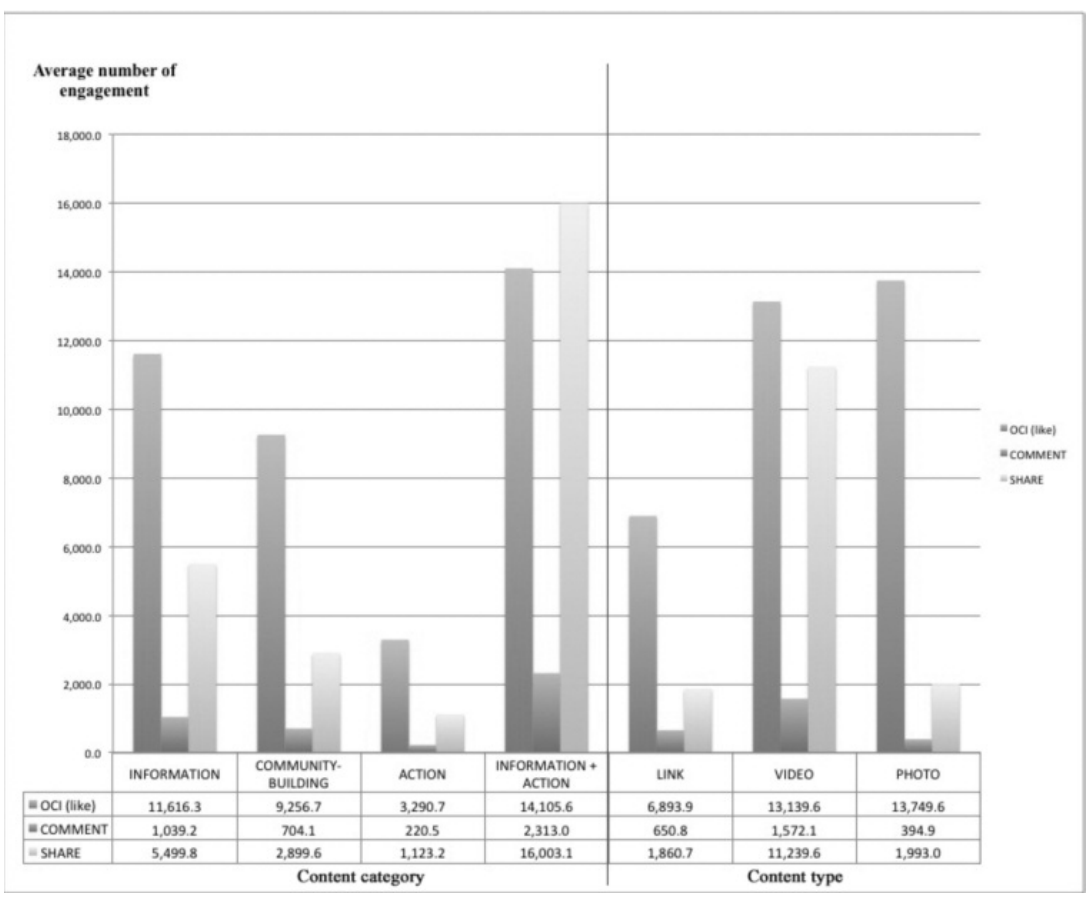

Figure 2: Percentages of content category per content type

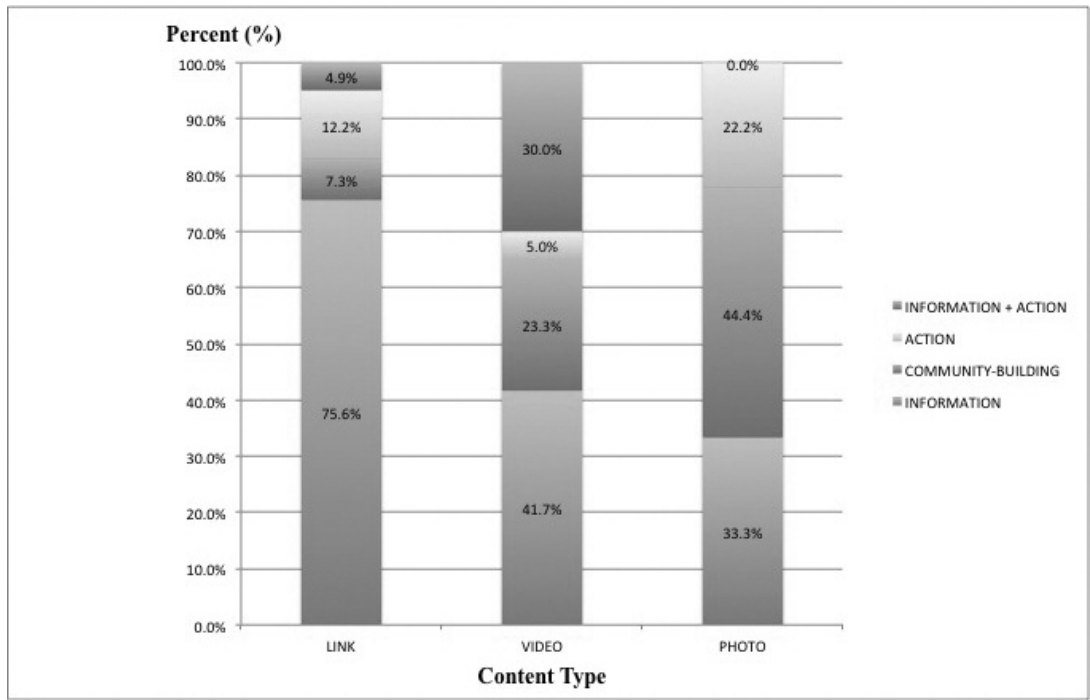


Review of the posts by area shows that in the examined period, the highest percentage of posts (34.5\%), were from Entertainment area. Such finding was unexpected, since the literature points out that Entertainment is not among the most important areas to animal rights advocates (Shani, 2012). However, at that time one of the ongoing PETA's campaigns was against Seaworld, an amusement park with orcas (PETA, 2016). Consequently, almost one third of the Entertainment content was related to Seaworld, which offers an explanation for the prevalence of $E n$ tertainment area posts. Furthermore, $29.1 \%$ of the content was related to Food area, only $10.0 \%$ to Fashion, and $11.8 \%$ to Testing area. A small percentage of content in Fashion area may be explained with seasonality, since data was collected in spring yet, wool and fur are trending in autumn and winter. Infrequency of Testing area content may be due to restricted access to laboratories, so visual materials and other information are hard to obtain. Lastly, $14.5 \%$ of the content did not fall into any of the specified four areas and was therefore assigned to category Other. Such posts, which were dominated by content related to dogs and cats for example, showcased a story of lost cat reunited with the owner, deadly consequences of eating litter for whales etc.
Each area received more $\mathrm{OCl}$ than shares or comments (Figure 3). Entertainment area received the highest number of $\mathrm{OCI}$ on average, potentially due to a number of positively orientated posts such as reporting how orca living in captivity was returned back to its natural environment. It can be argued that people find such content more pleasing and are therefore more inclined to click Like or similar. Figure 3 also illustrates that Food area received second highest number of $\mathrm{OCl}$ on average, followed by Testing, Fashion and Other area. In generating comments and shares, Food area also outperformed other areas. Such outstanding performance of Food area can be attributed to people's dislocation from the meat production process since consumption habits are not associated with cruelty (Plous, 1993). Consequently, people may find content, which vividly showcases production of steaks and products alike interesting, educational and shocking, and thus worth engaging with and sharing it with their network of friends. Area Other received far less engagement on average compared to the four areas. Accordingly, the finding of this study supports Bowmar and Gow (2009) that the four areas are the four most important areas in studied context.

Figure 3: Average numbers of engagement per area

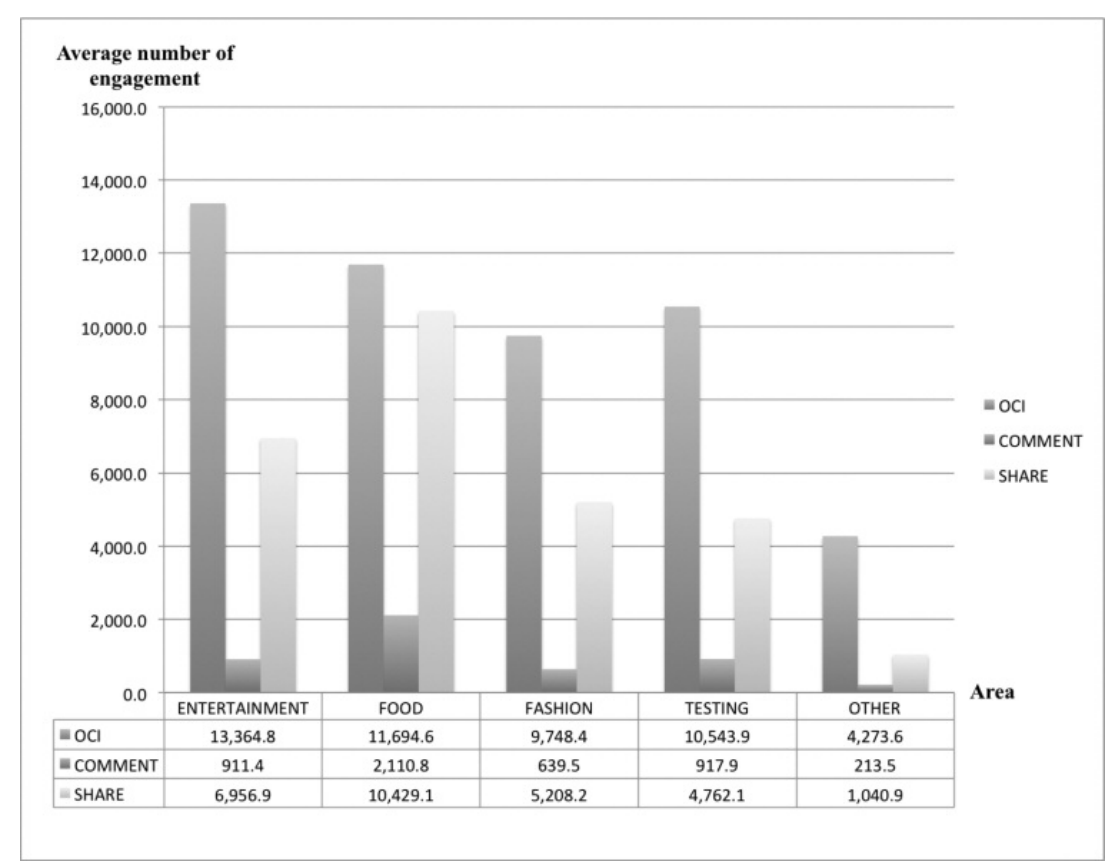


To analyse in-depth how people engage with the content, it is essential to examine comments since comments are reported to be the most captivating form of engagement. Table 3 presents the characteristics of the eight posts, which comments were analysed. All top performing posts in number of comments fall into categories with informational component.

The content on the chosen page is often shocking and unpleasant to watch. It showcases how animals are mistreated for entertainment, food, fashion or science purposes, since its main goal is to raise awareness on how animals are used and persuade viewers to abandon use of animals and opt for cruelty-free lifestyle. However, the first post in Entertainment area (Table 3 ) presents a very positive story about orca from Blackfish movie, which was transported to Iceland and released back to its natural environment. Consequently, such post was expected to generate more positive comments.

In the analysis of comments, category Supporting the content is prevailing at $54.7 \%$, followed by category Demanding a change (15.0\%), Contradicting the content (11.6\%), Epiphany (9.7\%), Suggesting alternatives (5.0\%) and Asking questions (4.1\%). The prevailing category is also reflected in Figure 4 (generated with Wordle), since words that are frequently used in supportive comments appear in larger font. The prevalence of Supporting category was expected, since the most common factors why people contribute on Facebook are venting negative feelings, showing concern and obtaining social benefits (Brodie et al., 2013).

Supporting category also dominated across all four areas, with the lowest amount of comments in Food area (Figure 5). According to Knight and Barnett (2008), people hold more favorable views towards using animals for food, which is perceived as a necessity, and simultaneously hold rather negative attitudes toward using animals for entertainment and fashion purposes. This study shows consistent findings, since the two areas showcase a higher percentage of Supporting comments compared to Food area.

Table 3: Eight posts for analysis of Comments

\begin{tabular}{|c|c|c|c|c|c|}
\hline & Area & Number of comments & Type & Category & Post's story \\
\hline 1 & Entertainment & 6,956 & Video & Informational & $\begin{array}{l}\text { Orca from Blackfish movie was introduced back } \\
\text { to its natural environment. }\end{array}$ \\
\hline 2 & Entertainment & 3,400 & Video & Informational + Action & $\begin{array}{l}\text { Showcasing abuse of animals in circuses and } \\
\text { urge to boycott circuses }\end{array}$ \\
\hline 3 & Food & 27,350 & Video & Informational + Action & $\begin{array}{l}\text { Chicken in reverse - presenting the Chicken } \\
\text { wings production process in reverse - back to } \\
\text { the living chicken. }\end{array}$ \\
\hline 4 & Food & 5,329 & Video & Informational & $\begin{array}{l}\text { Graphically presenting the process that pigs } \\
\text { undergo in slaughterhouse. }\end{array}$ \\
\hline 5 & Fashion & 2,141 & Video & Informational & $\begin{array}{l}\text { Leather goods containing intestines, flesh and } \\
\text { other organs were positioned in a shop to shock } \\
\text { customers and raise awareness. }\end{array}$ \\
\hline 6 & Fashion & 1,077 & Link & Informational & $\begin{array}{l}\text { Rabbits slaughtered for real-fur pillows sold by } \\
\text { retailer Simson. }\end{array}$ \\
\hline 7 & Testing & 3,695 & Video & Informational + Action & $\begin{array}{l}\text { Showcasing cruel test on monkeys in Tobacco } \\
\text { industry. }\end{array}$ \\
\hline 8 & Testing & 2,899 & Link & Informational & $\begin{array}{l}\text { Presenting mistreatment of Lab monkeys and } \\
\text { cruel physical and psychological consequences } \\
\text { that these monkeys endured. }\end{array}$ \\
\hline
\end{tabular}




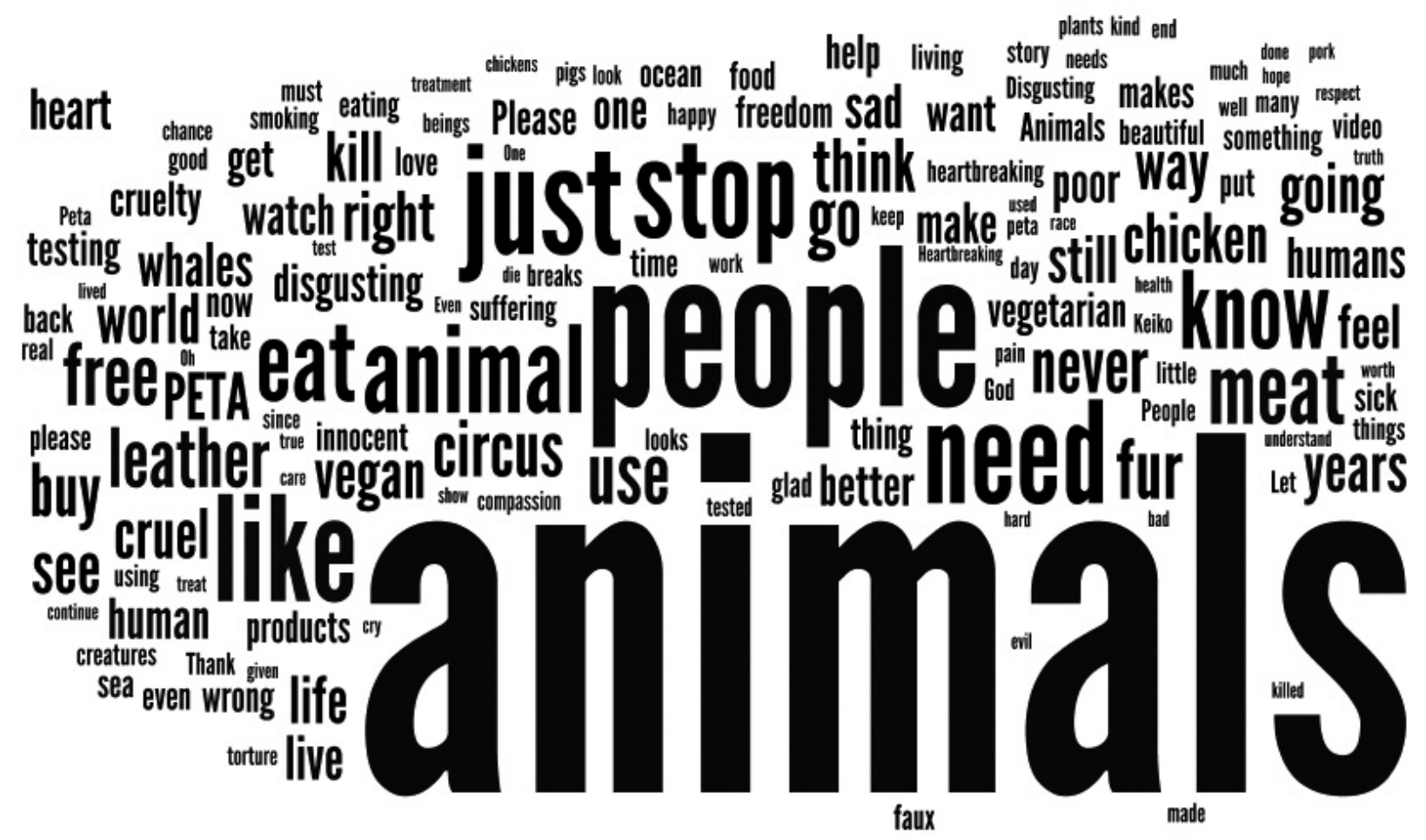

One could suggest that such page only generates engagement from social media users who support the organisation's objectives. This may hold to a certain extent; however, what sort of content Facebook users see in their News Feed depends on a complex Facebook algorithm, which is highly classified information. Nevertheless, Facebook tends to include into one's News Feed content that is shared multiple times, was produced by a friend that the user interacts with frequently, content that has a high statistical probability that a particular individual will like, content that was published recently and most importantly content that one's friends interacted with (Constine, 2016). Hence, content from PETA Facebook page is displayed also to follower's friends who may not follow PETA or agree with their views. Consequently, it is expected that content published on PETA Facebook page is expected to generate supportive as well as fairly negative comments.

Figure 5 displays that Supporting the content is lower and Contradicting the content is higher in Food and Fashion than in Entertainment and Testing area.
Such finding points to cognitive dissonance, since consumers may find it difficult to absorb new information and adapt their habits accordingly. The rationale may lay in the fact that habits in Fashion and Food area may be more deeply enrooted in consumers' traditions, culture and upbringing. To illustrate, people appreciate wool, leather and fur for aesthetic purposes and these materials have been used since prehistoric times and therefore are deeply rooted in culture and tradition (Stone, 2008). Consequently, many participants showcase rejection, objectification and search for benefits, in form of Contradicting comments, in order to justify their unethical behavior. Furthermore, Food area generated the highest amount of Contradicting comments (26.3\%) and the smallest difference in number of Supporting and Contradicting comments, at 12.5 percentage points (Figure 5). According to de Vries et al., (2012) a high percentage of positive or negative comments compared to neutral comments tends to contribute to more comments. Their finding is supported; the post, which generated the most 
comments in Food area, generated almost four times as many comments as the post with the second highest number of comments (Table 3). Such finding is not reflected in only one post but also in general, since Figure 3 presents that Food area received by far the highest amount of comments on average.

Figure 5 illustrates that comments showcasing Epiphany and Asking questions were more common in Food and Fashion area compared to other areas, which points to dislocation from the process. Such findings are in line with Plous (1993), who argues that people are not familiar with meat production process since the end product hardly resembles a living being. However, when information is presented to an individual that often results in shock and cognitive dissonance. Moreover, it appears that people do not suffer from dislocation process only in Food area, as Plous (1993) argues, but also to a certain extent in Fashion area.

Furthermore, the findings demonstrate that Entertainment area has the second highest percentage of comments Demanding a change and by far the highest percentage of comments Supporting content, which presents that participants almost unanimously agree that using animals for entertainment purposes is unethical, cruel, and should be aban- doned. The finding therefore contradicts Furnham et al. (2003) who argue that people tend to hold less positive attitudes toward practices, which are lethal for the animal in contrast to non-lethal, observational practices such as zoos and circuses.

When analyzing comments, which fall into Testing area, it is apparent that participants strongly oppose animal testing, even for scientific purposes, since Venting negative feelings and Demanding a change are the most present in Testing area. Besides, not even one comment out of 80 in Testing area showed favorable attitudes towards animal testing. Consequently, this contradicts Atkins-Sayre (2010) who identified that people tend to support more the use of animals, which has a higher purpose such as animal testing in order to discover a new cure.

The prevailing category Supporting the content, can be divided further into Venting negative feelings and Other, which includes Individual's examples, opinions, concerns etc. In all four main areas subcategory Venting negative feelings is dominating over subcategory Other. Interestingly, in Testing and Food area comments coded as Venting negative feelings are prevailing at $92.0 \%$ and $90.3 \%$, respectively. In contrast, the dominance of subcategory Venting negative feelings is much smaller in Fashion area, at 26.3

Figure 5: Types of interactions and four main areas

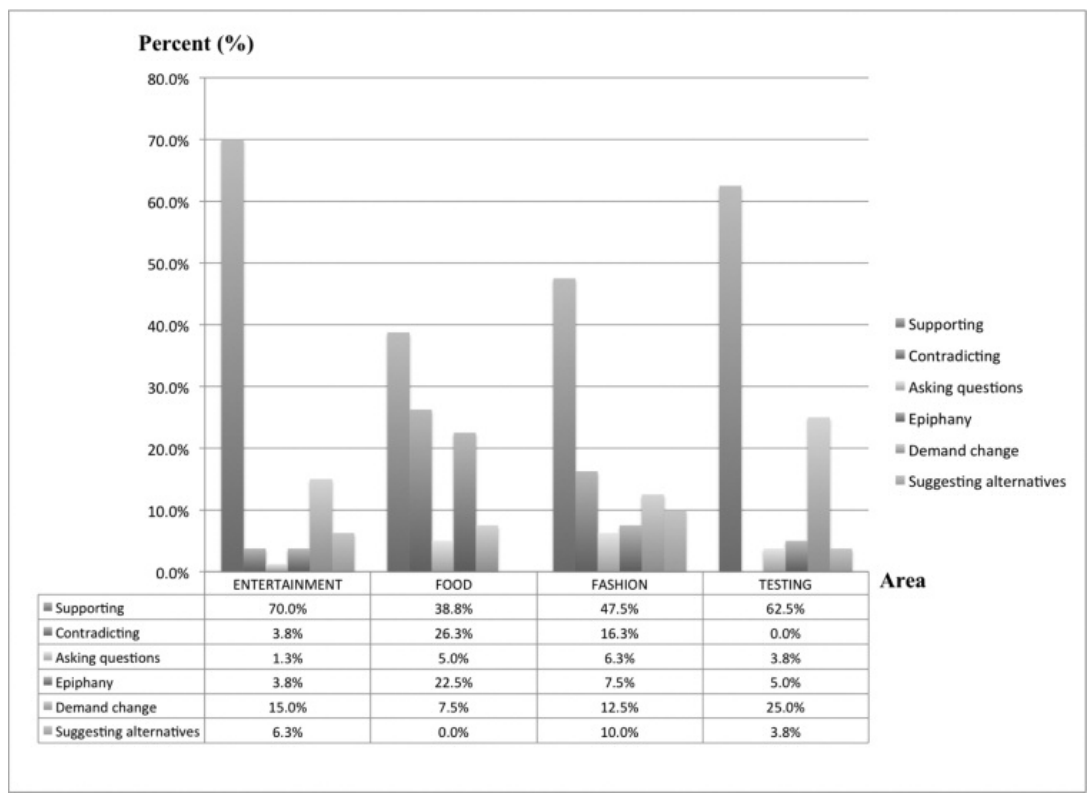


Patricia Fux, Barbara Čater: Analysis of Interactions on Non-Profit Organization's Social Media Channel in the Context of Cruelty-Free Ethical Consumerism

percentage points and the lowest in Entertainment area at only 14.3 percentage point difference. Comments, which are venting negative feelings, are enhanced by content that is shocking and vividly presents cruel processes. Such conclusion derives from the fact that one of the analyzed Entertainment posts was significantly positive, whereas analyzed posts from Food and Testing area vividly showcased meat production and animal testing processes.

It can be summarized that comments Supporting the content are the most frequent in all four areas. However, a higher percentage of such comments is noted in Entertainment and Testing area, which also showcased a high percentage of Demanding a change comments. Conversely, Food and Fashion area received less Supporting comments and more comments coded as Contradicting, Epiphany and Asking question, compared to Entertainment and Testing. Consequently, these results show that people are less inclined towards using animals for entertainment and testing purposes and less informed and knowledgeable about use of animals for food and fashion purposes. Additionally, Food and Fashion area generated more diverse comments, since the differences between coding categories are smaller, which appears to stimulate more comments, since Food area generated far more comments compared to others.

\section{DISCUSSION}

Even though these research findings derive from a qualitative research technique, they may also be very insightful to NPOs working on a variety of different social causes. This study points out that lack of awareness and knowledge is one of the main factors influencing why people do not behave ethically and therefore do not follow the studied organization's main goal. However, once awareness and information are gained, individual may reach epiphany and in such cases a willingness to change behaviour was observed. When epiphany, cognitive dissonance or a willingness to change behaviour were observed, the individual showed support to organization's main goal. Consequently, the research shows that providing valuable information is of crucial importance to spark engagement and create new supporters. Based on the insights of this study some important theoretical as well as practical implications arise that are discussed next.

Lovejoy and Saxton (2012) developed an Information - Community Building - Action scheme where Information content provides traditional oneway messages, Community building content sparks debate and content categorized as Action invites the follower to take action. However, in our study we have observed that when informational content contains action features as well, such content proved to be the best in generating engagement. Moreover, such content seems to generate especially high amount of engagement if presented in video type that was discovered to be the type, which received the most engagement. Majority of videos in our sample were graphically presenting mistreatment of animals. Such content is often shocking as its purpose is primarily to inform, educate, shock and persuade the viewer to change deeply enrooted habits, such as eating meat or wearing fur (Olson \& Goodnight, 1994). Hence, it can be concluded that viewers find such content interesting and therefore worth sharing it with their network of friends and acquaintances. Consequently, we propose that NPOs and organizations alike should primarily focus on video content, which educates followers on critical issues in order to receive their attention. After a viewer is educated on the issue, the content should also present a way to take action in order to convert the viewer into an active supporter of the advocated cause.

The finding that content with informational component performed well in generating all types of engagement is consistent with Cvijikj and Michahelles $(2011,2013)$ as they report Information category to outperform others in Like, Comment and Share engagement, and Saxton and Waters (2014) who report such content to perform well in generating Comments and Shares. Moreover, Cvijikj and Michahelles (2013) and Laurn et al. (2015) also report video type to perform exceptionally well in generating engagement. Such findings are aligned with OECs' main goal, which is to share information and raise awareness on critical ethical issues (Uusitalo \& Oksanen, 2004; Rodan \& Mummery, 2016). Consequently, also in the area of ethical consumerism content with informational component is perceived as meaningful and worth engaging with. 
Conversely, Action category performed the worst in all three types of engagement. This finding is inconsistent with findings of Cvijikj and Michahelles (2013), Saxton and Waters (2014) and Luarn et al. (2015), since they report good performance of the category in generating likes. However, Action content is mainly inviting followers to attend boycotts and sign petitions. Hence, it can be assumed that such posts are perceived as relevant only to the most loyal followers, which in turn explains the poor performance in terms of engagement in contrast to other categories.

Different social issues are led by different motives and therefore ways in which information is presented should differ significantly. This study points out that cruelty-free ethical consumerism is, similarly to Fair-trade topic, predominantly led by altruistic motives, since content primarily appeals to empathy and emotions, which, according to Murphy and Jenner-Leuthart (2011), increases awareness and tend to convince followers to develop stronger attitudes toward the issue. Consequently, NPOs and organizations alike focusing on altruistic motives should provide "true-story" informational content, which educates and appeals to emotions. Contrarily, according to Michaelidou and Hassan (2008) NPOs targeting primarily individual's egoistic motives should provide factual informational content focusing on egoistic motives such as health benefits, for instance.

Additionally, the study also reveals that people do not hold unidimensional views towards the use of animals; they hold different views toward different studied areas. Such differences can be explained with lack of knowledge about certain topic. Our study points out that Fashion and Food area showcased a high amount of comments showing epiphany and disagreement with the content, which implies that contributors are not familiar with the processes how animals are used or faces cognitive dissonance - a misalignment of beliefs and behaviour. Consequently, the research shows that social media provide a valuable source of information regarding the topic that does not receive much attention in other media types and that such communities serve as a platform to discuss social issues and are contributing to raising awareness. Moreover, if sufficient information is provided, consumers tend to become less price-sensitive, more ethically conscious and more willing to translate their attitudes and intentions into behavior (Murphy \& Jenner-Leuthart, 2011).

Every study, every research design has its advantages and limitations. Next we present the most important limitations of this study and suggestions for future research, which could contribute to a more detailed and multi-aspect understanding of the main research question. The first set of limitations pertains to sample size. This study collected only one month of content and it was observed that there were very few posts related to the use of animals in Fashion area, which is potentially due to seasonality since the chosen time frame was in spring and content related to fur and wool might be more trending during the winter. Accordingly, future research should choose a wider time frame to avoid the seasonality effect. Another limitation of this study is, besides examining only one social media channel, the focus on only one organization in a certain context. Consequently, to get results more applicable to a variety of different NPOs, charities and organizations alike, future studies should examine social media channels of more NPOs working on different social issues.

De Vries et al. (2012) report that a higher percentage of positive and negative comments compared to neutral comments tend to stimulate more comments, which is supported in this study. However, this study analysed only first-stage comments, which are directly related to the content and did not take into account the comments, which are made on comments, the second-stage comments. Therefore, future studies could look also at second stage comments to study what kinds of comments evoke debate between followers. Such studies would reveal how important is the social aspect of such communities compared to only receiving the information published by the page's admin.

Lastly, this study is based on the qualitative method netnography and therefore the findings are not generalizable. According to Kozinets (2002), the findings can become generalizable, if the method is triangulated with other methods such as surveys, interviews etc. Thus, future studies should use netnography together with other methods to make findings generalizable. Such research would be able to study the development of online relationships 
Patricia Fux, Barbara Čater: Analysis of Interactions on Non-Profit Organization's Social Media Channel in the Context of Cruelty-Free Ethical Consumerism

between NPO and its supporters from different angles and thus provide more detailed and precise findings. Furthermore, such study could also contribute to a better understanding whether and to what extent the social media content influences individual's attitudes, intentions and whether the intentions actually transform into behaviour.

Despite the limitations this study still contributes to a better understanding of behavioural and communication patterns related to ethical dis- course, which does not receive much attention in traditional media. The findings and implications can be relevant to a wide array of NPOs in order to create meaningful content, which sparks conversation, engagement and contributes to cultivating and maintaining long-term relationships with supporters. Our findings support the thesis that social media provide NPOs the much-needed platform for development and maintenance of relationship with their stakeholders (Mano, 2014).

\section{EXTENDED SUMMARY / IZVLEČEK}

Družbena omrežja so za neprofitne organizacije nov, priročen in cenovno ugoden medij, preko katerega lahko širijo svoja sporočila, povečajo zavedanje posameznikov, se povežejo s podporniki in dosežejo široko javnost. Glavni cilj te študije je bil preučiti interakcije na izbranem družbenem omrežju, z namenom, da bi bolje razumeli, kako se posamezniki odzivajo na vsebine, ki jih objavljajo neprofitne organizacije. Študija je postavljena v kontekst etične potrošnje brez krutosti, pri čemer so bili podatki za analizo pridobljeni z uradne Facebook strani mednarodne neprofitne organizacije PETA. Rezultati študije kažejo, da sta prav pomanjkanje zavedanja in poznavanja dva najpomembnejša vzroka, da se ljudje (še) ne vedejo etično in posledično ne sledijo glavnemu cilju organizacije. Ko pa posameznik pridobi potrebne informacije za odločanje, lahko pride do uvida, spoznanja, da njegovo vedenje do sedaj ni bilo etično in pokaže željo po spremembi vedenja. $V$ teh primerih je bila istočasno zaznana tudi večja podpora glavnemu cilju organizacije. Izsledki študije so pokazali, da so največ interakcij prejele prav objave z vsebino informacijske narave in prav pri njih so bili prevladujoči komentarji z izrazi podpore objavljenim vsebinam. Vsebine informativne narave veljajo za zelo pomembne in koristne, posebno kadar posameznik nima veliko znanja o konkretni temi. Glede na ugotovitve so informativne vsebine še posebno priporočene neprofitnim organizacijam za učinkovito povečanje zavedanja javnosti, pridobivanje novih podpornikov in ohranjanje dolgoročnih odnosov z obstoječimi podporniki.

\section{REFERENCES}

Atkins-Sayre, W. (2010). Articulating identity: People for the Ethical Treatment of Animals and the animal/human divide. Western Journal of Communication, 74(3), 309-328.

Auger, G. (2013). Fostering democracy through social media: Evaluating diametrically opposed nonprofit advocacy organizations' use of Facebook, Twitter, and YouTube. Public Relations Review, 39(4), 369-376.

Balls, M. (1992). What should the cosmetic industry do about the animal testing controversy?. International Journal of Cosmetic Science, 14(1), 1-9.
Bandyopadhyay, S., \& Dayton, C. (2013). Survival of the fittest: Developing a cost-effective branding strategy for nonprofit organization to survive and thrive in a competitive environment. South Shore Journal, 5, 183-202.

Berthon, P., Pitt, L., Plangger, K., \& Shapiro, D. (2012). Marketing meets Web 2.0, social media, and creative consumers: Implications for international marketing strategy. Business Horizons, 55(3), 261-271.

Bowmar, R., \& Gow, H. (2009). Alternative strategic responses to the animal welfare advocacy: The case of PETA, merino wool and the practice of mulesing. In 17th International Farm Management Congress (pp. 3-42). Illinois, USA: 17th International Farm Management Congress. 
Braunsberger, K., \& Buckler, B. (2011). What motivates consumers to participate in boycotts: Lessons from the ongoing Canadian seafood boycott. Journal of Business Research, 64(1), 96-102.

Brodie, R., Ilic, A., Juric, B., \& Hollebeek, L. (2013). Consumer engagement in a virtual brand community: An exploratory analysis. Journal of Business Research, 66(1), 105-114.

Campbell, D. A., Lambright, K. T., \& Wells, C. J. (2014). Looking for friends, fans, and followers? Social media use in public and nonprofit human services. Public Administration Review, 74(5), 655-663.

Cho, S., \& Krasser, A. (2011). What makes us care? The impact of cultural values, individual factors, and attention to media content on motivation for ethical consumerism. International Social Science Review, 86(1), 3-23.

Cho, M., Schweickart, T., \& Haase, A. (2014). Public engagement with nonprofit organizations on Facebook. Public Relations Review, 40(3), 565-567.

Constine, J. (2016). How Facebook News feed works. Retrived from https://techcrunch.com/2016/09/06/ultimate-guide-to-the-news-feed/

Cvijikj, I., \& Michahelles, F. (2011). A case study of the effects of moderator posts within a Facebook brand page. In: A. Datta, S. Shulman, B. Zheng, S. D. Lin, A. Sun, \& E. P. Lim (Eds.), Social informatics (pp. 161170). Singapore: Springer.

Cvijikj, I., \& Michahelles, F. (2013). Online engagement factors on Facebook brand pages. Social Network Analysis and Mining, 3(4), 843-861.

Davis, L., Rountree, M. M., \& Davis, J. A. (2016). Global Cause Awareness: Tracking Awareness Through Electronic Word of Mouth. Journal of Nonprofit \& Public Sector Marketing, 28(3), 252-272.

de Vries, L., Gensler, S., \& Leeflang, P. (2012). Popularity of Brand Posts on Brand Fan Pages: An Investigation of the Effects of Social Media Marketing. Journal of Interactive Marketing, 26(2), 83-91.

Dholakia, U., Blazevic, V., Wiertz, C., \& Algesheimer, R. (2009). Communal Service Delivery: How Customers Benefit From Participation in Firm-Hosted Virtual P3 Communities. Journal of Service Research, 12(2), 208-226.

Driscoll, K. (2009). Non-profits find new friends in new media. Rouchester Business Journal, 25(2), 22.

Facebook users worldwide 2017 / Statistic. (2018). Statista. Retrieved from http://www.statista.com/statistics/264810/numberof-monthly-active-facebook-users-worldwide/

Facebook.com. (2016a). How are comments shown on Page posts?. Retrived from https://www.facebook.com/help/539680519386145
Facebook.com. (2016b). PETA. Retrived from: https://www.facebook.com/official.peta/ [Accessed 22/06/2016].

Furnham, A., McManus, C., \& Scott, D. (2003). Personality, empathy and attitudes to animal welfare. Anthrozoos: A Multidisciplinary Journal of the Interactions of People \& Animals, 16(2), 135-146.

Goldkind, L. (2015). Social Media and Social Service: Are Nonprofits Plugged in to the Digital Age?. Journal Human Service Organizations: Management, Leadership \& Governance, 39(4), 380-396.

Gummerus, J., Liljander, V., \& Sihlman, R. (2017). Do ethical social media communities pay off? An exploratory study of the ability of Facebook ethical communities to strengthen consumers' ethical consumption behavior. Journal of Business Ethics, 144(3), 449-465.

Hamilton, M. (2006). Eating Death. An International Journal of Multidisciplinary Research, 9(2), 156-177.

Herzog, H. (1993). "The Movement Is My Life": The psychology of animal rights activism. Journal of Social Issues, 49(1), 103-119.

Huang, F. H. (2013). Motivations of Facebook users for responding to posts on a community page. In A. A. Ozok \& P. Zaphiris (Eds.), Online Communities and Social Computing (pp. 33-40). Berlin: Springer.

Jayasingh, S. \& Venkatesh, R. (2015). Customer Engagement Factors in Facebook Brand Pages. Asian Social Science, 11(26),19-29.

Johnson, D. (1990, February 12). Some view battle in snow country as turning point in war over fur. The New York Times, p.18.

Joinson, A. (2008). 'Looking at', 'looking up' or 'keeping up with' people? Motives and uses of Facebook. In 26th Annual CHI Conference on Human Factors in Computing Systems, (pp. 1027-1036). Bath: University of Bath.

Kietzmann, J., Hermkens, K., McCarthy, I., \& Silvestre, B. (2011). Social media? Get serious! Understanding the functional building blocks of social media. Business Horizons, 54(3), 241-251.

Kim, D., Spiller, L., \& Hettche, M. (2015). Analyzing media types and content orientations in Facebook for global brands. Journal of Research in Interactive Marketing, 9(1), 4-30.

Knight, S., \& Barnett, L. (2008). Justifying attitudes toward animal use: A qualitative study of people's views and beliefs. Anthrozoos: A Multidisciplinary Journal of the Interactions of People \& Animals, 21(1), 31-42.

Knight, S., Vrij, A., Cherryman, J., \& Nunkoosing, K. (2004). Attitudes towards animal use and belief in animal mind. Anthrozoos: A Multidisciplinary Journal of the Interactions of People \& Animals, 17(1), 43-62.

Kozinets, R. (2002). The field behind the screen: Using netnography for marketing research in online communities. Journal of Marketing Research, 39(1), 61-72. 
Patricia Fux, Barbara Čater: Analysis of Interactions on Non-Profit Organization's Social Media Channel in the Context of Cruelty-Free Ethical Consumerism

Kozinets, R. (2015). Netnography: Redefined. (2nd ed., pp. 80,98-99,141,162,172-175,221,274). London: Sage Publications.

Lin, K., \& Lu, H. (2011). Why people use social networking sites: An empirical study integrating network externalities and motivation theory. Computers In Human Behavior, 27(3), 1152-1161.

Lovejoy, K., \& Saxton, G. (2012). Information, community, and action: How nonprofit organizations use social media. Journal of Computer-Mediated Communication, 17(3), 337-353.

Luarn, P., Lin, Y., \& Chiu, Y. (2015). Influence of Facebook brand-page posts on online engagement. Online Information Review, 39(4), 505-519.

Lundblad, L., \& Davies, I. (2015). The values and motivations behind sustainable fashion consumption. Journal of Consumer Behaviour, 15(2), 149-162.

Mano, R. (2014). Social media, social causes, giving behavior and money contributions. Computers in Human Behavior, 31, 287-293.

Michaelidou, N., \& Hassan, L. (2008). The role of health consciousness, food safety concern and ethical identity on attitudes and intentions towards organic food. International Journal of Consumer Studies, 32(2), 163-170.

Molm, L. (2010). The structure of reciprocity. Social Psychology Quarterly, 73(2), 119-131.

Molm, L., Collett, J., \& Schaefer, D. (2007). Building solidarity through generalized exchange: A theory of reciprocity. American Journal of Sociology, 113(1), 205-242.

Murphy, A., \& Jenner-Leuthart, B. (2011). Fairly sold? Adding value with fair trade coffee in cafes. Journal of Consumer Marketing, 28(7), 508-515.

Nah, S., \& Saxton, G. D. (2012). Modeling the adoption and use of social media by nonprofit organizations. New Media \& Society, 15(2), 294-313.

Olson, K., \& Goodnight, G. (1994). Entanglements of consumption, cruelty, privacy, and fashion: The social controversy over fur. Quarterly Journal of Speech, 80(3), 249-276.

People for the Ethical Treatment of Animals (PETA). (2016). PETA. Retrieved from http://www.peta.org

Persuad, A., Madill, J., \& Rubaj, A. (2009). Website marketing in Canadian non-profit organizations: an exploration of strategies, approaches and usability. In ASAC. Niagra Falls: Wilfrid Laurier University. Retrieved from http://ojs.acadiau.ca/index.php/ASAC/article/view/515/424

Phethean, C., Tiropanis, T., \& Harris, L. (2015). Engaging with charities on social media: Comparing interaction on Facebook and Twitter. In T. Tiropanis, A. Vakali, L. Sartori \& P. Burnap, Internet Science (pp. 15-29). Retrieved from http://dx.doi.org/10.1007/978-3-319-18609-2_2

Plous, S. (1993). Psychological mechanisms in the human use of animals. Journal of Social Issues, 49(1), 11-52.
Rodan, D., \& Mummery, J. (2016). Doing animal welfare activism everyday: questions of identity. Continuum, 30(4), 1-16.

Ruiz-Mafe, C., Martí-Parreño, J., \& Sanz-Blas, S. (2014). Key drivers of consumer loyalty to Facebook fan pages. Online Information Review, 38(3), 362-380.

Sabate, F., Berbegal-Mirabent, J., Cañabate, A., \& Lebherz, P. (2014). Factors influencing popularity of branded content in Facebook fan pages. European Management Journal, 32(6), 1001-1011.

Saxton, G., \& Waters, R. (2014). What do stakeholders like on Facebook? Examining public reactions to nonprofit organizations' informational, promotional, and community-building messages. Journal of Public Relations Research, 26(3), 280-299.

Shani, A. (2012). A quantitative investigation of tourists' ethical attitudes toward animal-based attractions. Tourism, 60(2), 139-158.

Singer, P. (2006). In defense of animals. Malden, MA: Blackwell Pub.

Stone, E. (2008). The dynamics of fashion. New York: Fairchild. Tallontire, A., Rentsendorj, E., \& Blowfield, M. (2001). Ethical consumers and ethical trade: A review of current literature (1st ed.). Natural Resources Institute, University of Greenwich. Retrieved from http://www.nri.org/projects/publications/policyseries/PolicySeriesNo12.pdf

UK Parliament. (2017). Stronger Charities for a Stronger Societies (pp. 3-9). House of Lords. Retrieved from ttps://publications.parliament.uk/pa/ld201617/Idselect/ldchar/133/133.pdf

Uusitalo, O., \& Oksanen, R. (2004). Ethical consumerism: a view from Finland. International Journal of Consumer Studies, 28(3), 214-221.

Valerio, G., Herrera-Murillo, D., Villanueva-Puente, F., Herrera-Murillo, N., \& Rodríguez, M. (2015). The relationship between post formats and digital engagement: a study of the Facebook pages of Mexican universities. RUSC. Universities and Knowledge Society Journal, 12(1), 50.

Waters, R. D., Burnett, E., Lamm, A., \& Lucas, J. (2009). Engaging stakeholders through social networking: How nonprofit organizations are using Facebook. Public Relations Review, 35(2), 102-106.

Waters, R. D., \& Feneley, K. L. (2013). Virtual stewardship in the age of new media: Have nonprofit organizations' moved beyond web 1.0 strategies?. International Journal of Nonprofit and Voluntary Sector Marketing, 18(3), 216-230.

Wordle. (2016). Wordle.net. Retrieved from http://www.wordle.net/create

Wyrwoll, C. (2014). Social Media. Wiesbaden: Springer Fachmedien Wiesbaden. 